\title{
A climatology of the diurnal variations in stratospheric and mesospheric ozone over Bern, Switzerland
}

\author{
S. Studer ${ }^{1,2}$, K. Hocke ${ }^{1,2}$, A. Schanz ${ }^{1,2}$, H. Schmidt ${ }^{3}$, and N. Kämpfer ${ }^{1,2}$ \\ ${ }^{1}$ Institute of Applied Physics, University of Bern, Bern, Switzerland \\ ${ }^{2}$ Oeschger Center for Climate Change Research, University of Bern, Bern, Switzerland \\ ${ }^{3}$ Max Planck Institute for Meteorology, Hamburg, Germany
}

Correspondence to: K. Hocke (klemens.hocke@iap.unibe.ch)

Received: 27 July 2013 - Published in Atmos. Chem. Phys. Discuss.: 29 August 2013

Revised: 1 May 2014 - Accepted: 7 May 2014 - Published: 16 June 2014

\begin{abstract}
The ground-based radiometer GROMOS, stationed in Bern $\left(47.95^{\circ} \mathrm{N}, 7.44^{\circ} \mathrm{E}\right)$, Switzerland, has a unique data set: it obtains ozone profiles from November 1994 to present with a time resolution of $30 \mathrm{~min}$ and equivalent quality during night- and daytime. Here, we derive a monthly climatology of the daily ozone cycle from 17 years of GROMOS observation. We present the diurnal ozone variation of the stratosphere and mesosphere. Characterizing the diurnal cycle of stratospheric ozone is important for correct trend estimates of the ozone layer derived from satellite observations. The diurnal ozone cycle from GROMOS is compared to two models: the Whole Atmosphere Community Climate Model (WACCM) and the Hamburg Model of Neutral and Ionized Atmosphere (HAMMONIA). Generally, observation and models show a good agreement: in the lower mesosphere, daytime ozone is for both GROMOS and models around $25 \%$ less than midnight ozone. In the stratosphere, ozone reaches its maximum in the afternoon showing values several percent larger than the midnight value. Further, GROMOS and models indicate a seasonal behaviour of the diurnal ozone variations in the stratosphere with a larger afternoon maximum during daytime in summer than in winter. Using the 17 years of ozone profiles from GROMOS, we find strong interannual variations in the diurnal ozone cycle for both the stratosphere and the mesosphere. Interannual variability in temperature, atmospheric circulation and composition may explain the observed interannual variability of the diurnal ozone cycle above Bern.
\end{abstract}

\section{Introduction}

There are numerous reasons to study the diurnal variation in stratospheric and mesospheric ozone. The diurnal ozone variation can be utilized as a benchmark for photochemical and transport models (Herman, 1979; Pallister and Tuck, 1983). In addition, the diurnal ozone variation can serve as a natural test signal for remote sensing instruments and data retrieval techniques (Parrish et al., 2013). Further, an accurate assessment of the diurnal ozone variation is needed for a reliable trend detection in the global ozone distribution. Satellites are in different sun-synchronous orbits, and therefore they sample ozone data at different local solar time (LST). Merging of ozone data sets from different satellites without properly accounting for the diurnal ozone variation can result in a systematic bias in the determined ozone trend.

Bhartia et al. (2013) described the problem of the orbit drift of the NOAA satellites which host the Solar Backscatter UV (SBUV) experiment. Meanwhile, the SBUV experiment yields a 42-year series of global ozone measurements, which are a backbone for trend estimates of stratospheric ozone. According to Bhartia et al. (2013) the present knowledge on the diurnal ozone variation is not sufficient for a reliable correction of diurnal sampling effects in the ozone data series of SBUV. Observation and modelling indicate that the amplitude of the diurnal variation in stratospheric ozone is about a few percent (Haefele et al., 2008; Parrish et al., 2013). However sampling biases due to the small diurnal ozone variation have to be taken seriously since the expected recovery rate of the stratospheric ozone layer is small. Jonsson et al. (2009) predicted an ozone trend of about $+2 \%$ per decade in the middle stratosphere from 2010 to 2040. 
Just for remembering the basics, we would like to mention the reactions of the Chapman cycle (Chapman, 1930), which are most important for understanding of the diurnal ozone variation.

$$
\begin{array}{ll}
\mathrm{O}_{2}+h v & \rightarrow 2 \mathrm{O} \quad(\lambda<240 \mathrm{~nm}) \\
\mathrm{O}+\mathrm{O}_{2}+M & \rightarrow \mathrm{O}_{3}+M \\
\mathrm{O}_{3}+\mathrm{O} & \rightarrow 2 \mathrm{O}_{2} \\
\mathrm{O}_{3}+h v & \rightarrow \mathrm{O}_{2}+\mathrm{O} \quad(\lambda<1140 \mathrm{~nm})
\end{array}
$$

$M$ stands for an air molecule. In the daytime stratosphere, the catalytic NO cycle counteracts the ozone production by the Chapman cycle (Schanz et al., 2014). In the daytime mesosphere, catalytic ozone depletion by odd hydrogen has to be considered in addition to the Chapman cycle. The anticorrelation of ozone and temperature is mainly due to the temperature dependence of the rate coefficients of the Reactions (R3) and (R2) (Craig and Ohring, 1958; Barnett et al., 1975).

Regarding the past research on the diurnal variation of stratospheric ozone, it is evident that numerical simulations were in clear advance of the observations. Numerical simulations with a photochemical box model in the middle stratosphere at northern midlatitudes showed that ozone decreases for a short time of $1-2 \mathrm{~h}$ after sunrise by about $1 \%$ with respect to midnight ozone (Herman, 1979; Pallister and Tuck, 1983; Vaughan, 1982, 1984; Allen et al., 1984). Pallister and Tuck (1983) attributed the dip in morning ozone to the fast increase of NO after sunrise. Then ozone slowly accumulates and reaches a maximum of about $+3 \%$ in the late afternoon. In the following $2-3 \mathrm{~h}$ and after sunset, ozone decreases to its midnight value.

Observations of the small diurnal variation in stratospheric ozone were not so convincing. Using ground-based ozone microwave radiometry, Connor et al. (1994) found a diurnal variation in stratospheric ozone quite consistent with the results of the photochemical models. Self-critically they pointed out that the statistical significance of the measurements is not sufficient for clear observational evidence of the diurnal ozone variation. Haefele et al. (2008) investigated diurnal ozone variations in the stratosphere using ground-based radiometer measurements from Payerne, Switzerland, and two chemistry climate models (CCMs). Though the observations and the models showed the increase of stratospheric ozone during daytime, the study of Haefele et al. (2008) cannot be regarded as " $100 \%$ observational evidence". The problem is that ground-based ozone microwave radiometry could be influenced by the diurnal variation in tropospheric water vapour or other factors. Since the radiometer is at $491 \mathrm{~m}$ above sea level, it is impossible to prove that tropospheric opacity can be excluded as a possible cause of the retrieved diurnal variation in stratospheric ozone.

Using the ozone data set from SABER on the TIMED satellite, Huang et al. $(2008,2010 \mathrm{a})$ derived the diurnal ozone variation based on zonal means in the stratosphere. Huang et al. (2010a) found an increase of about $5 \%$ in af- ternoon ozone (day of year $85,28^{\circ} \mathrm{N}$ ), which agrees well with Haefele et al. (2008). An excellent place for spaceborne observation of the diurnal variation in stratospheric ozone is the International Space Station (ISS), which has a low orbit inclination of $52^{\circ}$ and thus a fast sampling in local solar time. Sakazaki et al. (2013) presented the global pattern of the diurnal variation in stratospheric ozone from data of the Superconducting Submillimeter Wave Limb Emission Sounder (SMILES) attached on the ISS. The observation period was October 2009 to April 2010. They further compared their results to two chemistry-transport models (CTMs). By analysing CTM data for the underlying mechanisms in the stratospheric diurnal ozone variations, they identified three different regimes: (1) variations at $20-30 \mathrm{~km}$ are caused by dynamics; (2) at 30-40 km, diurnal variations are caused by photochemistry; and (3) those at $40-50 \mathrm{~km}$ are caused by both dynamics and photochemistry.

All observations together could be regarded as sufficient evidence of the diurnal variation in stratospheric ozone. The most convincing ground-based observational evidence was presented by Parrish et al. (2013) using a large data set of a ground-based ozone microwave radiometer at the Mauna Loa Observatory $\left(3397 \mathrm{~m}\right.$ above sea level, $\left.19.5^{\circ} \mathrm{N}\right)$, where tropospheric opacity is very low. They provided a carefol data analysis of a large number of measurements and also discussed possible technical issues of the instrument, which may effect the retrieved diurnal ozone variation. Parrish et al. (2013) also compared the stratospheric ozone measurements of the radiometer at Mauna Loa to coincident measurements of the satellites AURA/MLS and NOAA/SBUV and found a good agreement. Finally the observational results of Parrish et al. (2013) confirmed the diurnal variation in stratospheric ozone which was firstly simulated by Herman (1979).

Since the results of the low-altitude ground-based microwave radiometers in Payerne and Bern (Haefele et al., 2008, present study) are similar to those of the high-altitude microwave radiometer of Parrish et al. (2013), we are confident that diurnal variations of tropospheric water vapour are correctly removed by the retrieval algorithm so that groundbased ozone microwave radiometry seems to be the most important tool for the characterization of the observation of the diurnal variation in stratospheric ozone besides spaceborne remote sensing of ozone with fast sampling in local solar time (e.g. geostationary satellite or ISS with low inclination orbit).

In this study we analyse the diurnal variation in ozone from 17 years of observations (November 1994-2011) of the GROMOS microwave radiometer at Bern. The GROMOS microwave radiometer was already active at the advent of the ozone hole. Lobsiger and Künzi (1986) reported on the nighttime increase of mesospheric ozone during winter 1985 using early ozone measurements of the GROMOS microwave radiometer at Bern. Unfortunately GROMOS was only campaign-based operated with different instrumental set-ups in the time from 1985 to 1994 so that an analysis 
of the early ozone measurements would be quite difficult in view of ozone trend analysis or characterization of the interannual variability of the diurnal ozone variation. The purpose of the present study is to learn about the average seasonal behaviour of the diurnal ozone variation. Secondly we are interested in the interannual variability of the diurnal variation in stratospheric ozone. Both aims of our study are important for planing a correction of diurnal sampling effects in groundand space-based measurements of stratospheric ozone.

It is beyond the scope of the present observational study to give a tutorial on the physics and chemistry of the diurnal variation in stratospheric ozone. For a tutorial, the reader is referred to a numerical simulation study of Schanz et al. (2014), who described the global, regional and seasonal behaviour of the diurnal ozone variation in the middle stratosphere.

Our manuscript is organized as follows. In Sect. 2, data sets from GROMOS and models are described, while Sect. 3 explains the methods of data analysis. Section 4 presents the monthly mean climatology of diurnal ozone variations from 50 to $0.2 \mathrm{hPa}(\sim 21$ to $59 \mathrm{~km})$, and the results from GROMOS are compared with the model outcomes from WACCM and HAMMONIA. Section 5 describes in more detail the mean seasonal variation (January to December) of the diurnal ozone cycle at $5.7 \mathrm{hPa}(\sim 35 \mathrm{~km})$ and $0.35 \mathrm{hPa}(\sim 55 \mathrm{~km})$. In Sect. 6, the interannual variability of the diurnal ozone variation on these two pressure levels is presented. Conclusions are given in Sect. 7.

\section{Data sources}

\subsection{GROMOS radiometer}

Since November 1994, the millimetre-wave radiometer GROMOS (GROund-based Millimeter-wave Ozone Spectrometer) has been continuously operated in Bern, Switzerland $\left(47.95^{\circ} \mathrm{N}, 7.44^{\circ} \mathrm{E} ; 550 \mathrm{~m}\right.$ a.s.1.). GROMOS observes the middle atmosphere in the north-east direction through detection of the collision-broadened emission of the ozone transition at $142.17504 \mathrm{GHz}$. The ozone line spectra are converted into vertical ozone profiles from the stratosphere to the lower mesosphere. The ozone data quality during nighttime is as good as during daytime since the measurement signal is the thermal microwave emission by ozone molecules. This characteristic of ground-based ozone microwave radiometry is of course most important for monitoring of the diurnal ozone variation, and it is not provided by any other groundbased measurement technique.

GROMOS is part of the Network for the Detection of Atmospheric Composition Change (NDACC), and its data set is used for cross-validation of satellite experiments, studies of ozone-climate interactions and middle atmospheric dynamics, as well as for long-term monitoring of the ozone layer in the stratosphere (Peter and Kämpfer, 1995; Peter et al., 1996;
Calisesi et al., 2001; Dumitru et al., 2006; Hocke et al., 2006; Steinbrecht et al., 2006; Hocke et al., 2007; Flury et al., 2009; Steinbrecht et al., 2009; Studer et al., 2012; Hocke et al., 2013).

From November 1994 to October 2011, a filter bench has been used for spectral analysis. In July 2009, GROMOS was upgraded and a fast Fourier transform spectrometer (FFTS) is used additionally as back end. The data set used here is the ozone time series from the 17 years of filter bench measurements. The 45-channel filter bench had a bandwidth of $1.2 \mathrm{GHz}$ with a frequency resolution varying from $200 \mathrm{kHz}$ at the line centre to $100 \mathrm{MHz}$ at the wings. Ozone profiling by the microwave radiometer is only interrupted in case of high humidity (just a few "tropical hours" during summer in Switzerland) and intervals of heavy rain when the ozone line becomes invisible due to strong tropospheric attenuation of the ozone line emission. Under normal conditions, the ozone line spectrum can be corrected for the tropospheric attenuation. Using the brightness temperature in the continuum of the spectrum (far wing of the line), the tropospheric opacity is determined (Ingold et al., 1998). The knowledge of the tropospheric opacity permits the so-called tropospheric correction, which means that the effect of tropospheric attenuation is removed from the measured ozone line spectrum.

From the tropospheric corrected line spectrum, vertical profiles of ozone volume mixing ratio (VMR) are determined in the retrieval process. The retrieval of the ozone profiles is based upon the optimal estimation method of Rodgers (1976) and atmospheric radiative transfer calculations as implemented by the Arts/Qpack software (Eriksson et al., 2005, 2011). Bandwidth and frequency resolution allow the retrieval of ozone profiles from approximately 25 to $65 \mathrm{~km}$. With an integration time of $30 \mathrm{~min}$, the total relative error of retrieved ozone profiles is of the order of $7 \%$ for the stratosphere and increases toward the lower and upper altitude limit (up to $20 \%$ at $20 \mathrm{~km}$ and up to $30 \%$ at $70 \mathrm{~km}$ ). These error estimates are based on recent and past intercomparisons of coincident data from GROMOS, ozonesondes, nearby lidars and satellites (Studer et al., 2013; Dumitru et al., 2006). The GROMOS radiometer is described in more detail by Peter (1997).

\subsection{WACCM model}

The Whole Atmosphere Community Climate Model (WACCM) is hosted at the National Center for Atmospheric Research (USA). It is a high top model with an upper boundary at about $150 \mathrm{~km}$ altitude, detailed photochemistry and wave-mean flow interactions permitting a rather realistic simulation of circulation, composition, energetics and dynamics of the earth's lower and middle atmosphere (Garcia et al., 2007; Marsh et al., 2007; Tilmes et al., 2007). The atmosphere model interacts with the individual land, ice, and ocean models of the Community Earth System Model 
(CESM). A coupler handles the data exchange between the models.

Our numerical simulation is based on version 4 of WACCM with a pre-configured data integration called F 2000 for the year 2000. This integration reads climatologies of sea surface temperature and ice coverage. Atmosphere and land model are actively simulated within this configuration. The WACCM chemistry module is from the Model for OZone And Related chemical Tracers, version 3 (MOZART-3), which includes a detailed chemistry of the stratosphere (Kinnison et al., 2007). WACCM is capable of reproducing the tidal seasonality (Chang et al., 2008). Using WACCM simulations, Pedatella et al. (2012) investigated the influence of sudden stratospheric warnings on the propagation of solar tides throughout the atmosphere. In order to simulate the diurnal ozone variation, the model time step was downscaled to $15 \mathrm{~min}$. For the comparison here, the grid point for Bern is $46^{\circ} \mathrm{N}$ and $5^{\circ} \mathrm{E}$, and the output is saved every four model steps, resulting in a time resolution of $1 \mathrm{~h}$. The vertical resolution of WACCM ranges from $1.1 \mathrm{~km}$ in the lower stratosphere to 3.5 above $65 \mathrm{~km}$.

\subsection{HAMMONIA model}

HAMMONIA (Hamburg Model of the Neutral and Ionized Atmosphere) is a three-dimensional general circulation and chemistry model developed at the Max Planck Institute for Meteorology in Hamburg, Germany (Schmidt et al., 2006). It is based on the ECHAM 5 atmospheric general circulation model (Roeckner et al., 2003, 2006). HAMMONIA includes important atmospheric dynamics, radiation, and chemistry and treats them interactively. It covers an approximate altitude range from the surface to $250 \mathrm{~km}$ on 119 pressure layers. HAMMONIA, like WACCM, is coupled to the MOZART chemistry module (MOZART-3). Dikty et al. (2010) compared upper mesospheric daytime variations ( 6 a.m. to 6 p.m.) of ozone and temperature in the tropics from HAMMONIA with observations of the satellite experiment TIMED/SABER. Beig et al. (2012) studied diurnal variations of ozone and temperature in the equatorial mesosphere by analysing data from the HAMMONIA model and the satellite experiment UARS/HALOE. Analysis of the diurnal and semidiurnal tides in the mesosphere and lower thermosphere in simulation data of HAMMONIA shows that many observational results of tides are reproduced by the model (Achatz et al., 2008; Yuan et al., 2008).

The model output from HAMMONIA used in the present study consists of 3-hourly ozone values, and the closest grid point to Bern at $45^{\circ} \mathrm{N}$ and $7.5^{\circ} \mathrm{E}$ has been used for the comparison with GROMOS. We therefore have eight ozone model values per day for the location of Bern. The vertical resolution increases from about $700 \mathrm{~m}$ in the lower and middle stratosphere to about $3 \mathrm{~km}$ in the mesosphere. HAMMONIA data used here are taken from 10 years of a freerunning simulation using as boundary conditions present-day greenhouse gas concentrations, climatological present-day sea surface temperatures and sea ice coverage, and constant solar irradiance representative of solar minimum conditions. The simulation is described in more detail by Schmidt et al. (2010).

\section{Data analysis}

\subsection{Ozone spectra from GROMOS}

For our analysis we derive monthly mean spectra of the ozone emission line. For a certain month all observed spectra within a certain interval of Universal Time (UT) are averaged. Time bins are chosen as 00:00, 01:00, 02:00, . 23:00 UT $\pm 1 \mathrm{~h}$. Obvious outliers in the measurements are rejected already before the averaging process. However we further reduce the effect of noise and small outliers by taking the median of the statistical ensemble of the spectra within a certain UT interval. Small outliers can be due to small instabilities and fluctuations of individual channels of the digital filter bench. Finally we get for each month 24 mean spectra which describe the mean diurnal variation of the ozone emission line. An advantage of this method is that the uncertainty of the mean spectrum can be assessed by means of the lower and upper quantiles of the spectrum ensemble.

Figure 1 shows the 24 mean spectra of brightness temperature in April 2008 (different colours) which are quite typical for the data quality in the present study. Because of the pressure-broadening of the ozone line, the line centre informs about mesospheric ozone (small frequency shift associated with low air pressure) and the line wing about the stratosphere and troposphere (large frequency shift associated with high air pressure). Brightness temperature is proportional to the spectral irradiance of the ozone line emission. The number of spectra averaged for a certain month ranges from around 800 to 1200 . Spectra measured during times of high tropospheric opacity ( $>1.2)$ are not included. The standard deviation is about $3 \mathrm{~K}$ at the line centre and $1 \mathrm{~K}$ at the line wing, while the error of the mean ranges from $0.1 \mathrm{~K}$ (line centre) to $0.03 \mathrm{~K}$ (line wing).

Figure 1a and $\mathrm{b}$ show the full spectra calculated by using the median (a) and the arithmetic mean values (b), respectively. A zoom of the line centre is given in Fig. 1c and d. Figure 1d shows larger fluctuations than c. Contrary to the arithmetic mean, the median calculation is able to suppress the influence from individual bad data, which sometimes can pass the outlier rejection routines. Bad data can exist due to fluctuations of single channels of the digital filter bench and time periods with high opacity values.

Figure 1c nicely shows the increase of ozone at nighttime (thick blue line), where the peak at the line centre is strongest due to the increase of mesospheric ozone. This diurnal variation of the ozone spectra agrees well with the early 
a) median

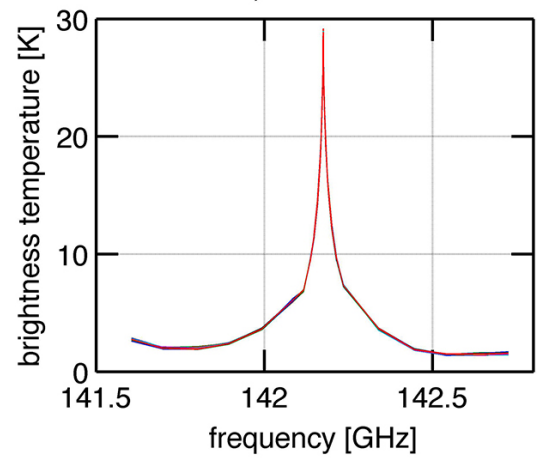

c) median

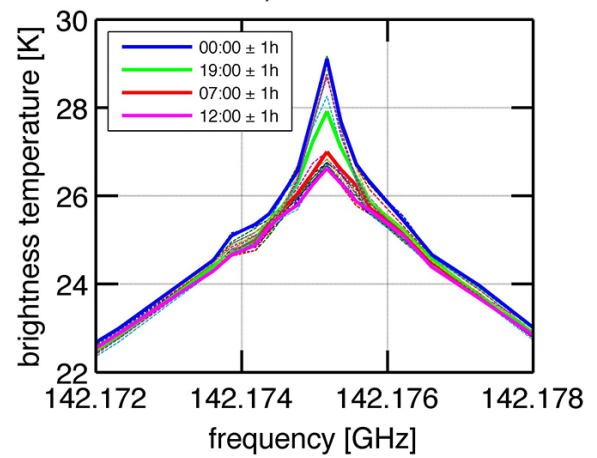

b) arithmetic mean

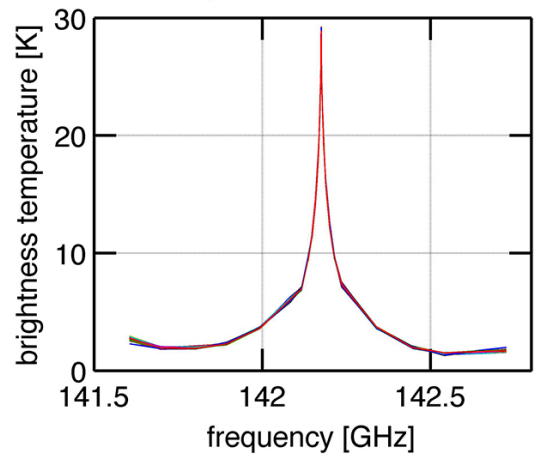

d) arithmetic mean

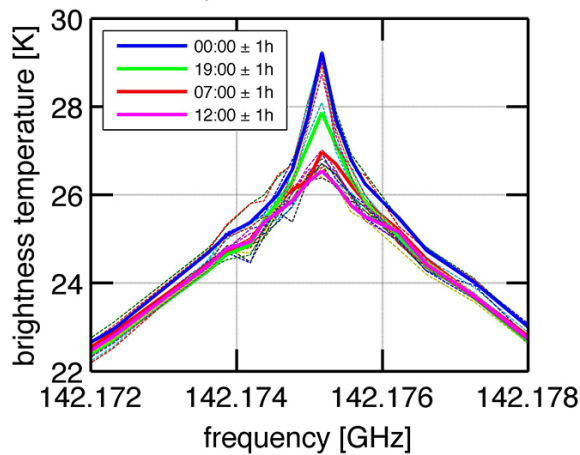

Figure 1. GROMOS spectra for April 2008, averaged with (a) median and (b) arithmetic mean. The averaged time intervals are taken as 00:00, 01:00, 02:00, ... 23:00 UT $\pm 1 \mathrm{~h}$, from all days of April 2008, resulting in 24 spectra per month. Different colours correspond to different time bins. A zoom into the line centre is given in (c) for the median calculation and (d) for the arithmetic mean, respectively. Four time bins are highlighted by the thick lines.

ozone spectra of GROMOS presented by Lobsiger and Künzi (1986).

In the following the diurnal ozone variation is described as function of local solar time (LST). LST is defined by $\mathrm{LST}=\mathrm{UT}+\phi \cdot 24 / 360 \mathrm{~h}$, where $\phi$ is the geographic longitude of the observation place and UT is the universal time.

\subsection{Ozone profiles from GROMOS}

The retrieval process derives an ozone profile from the mean ozone spectrum under consideration of the uncertainties of the model atmosphere and those of the measured ozone spectrum. Generally the retrieved ozone profile can be regarded as a mix of the a priori guess and information from the measurement. For GROMOS, the a priori ozone profiles are taken as a monthly mean climatology where no diurnal variation is included. Thus the diurnal ozone variation comes from the measurement and is not prescribed in the retrieval process.

Figure 2 (left panel) shows the mean retrieved profiles for January at Bern during nighttime (blue line) and daytime (magenta line), together with the a priori profile for January (red). The nighttime ozone increase in the mesosphere, as well as a daytime increase around $35 \mathrm{~km}$, is apparent.

The retrieval also provides the averaging kernels, which inform about the vertical resolution of the retrieved ozone profile. The two middle panels of Fig. 2 give the averaging kernels (AVKs) of the GROMOS retrieval for nighttime and daytime respectively. AVKs for altitude levels of 28 (blue), 40 (purple) and 52 (red) $\mathrm{km}$ are enhanced, and they peak at the corresponding altitude. The vertical resolution can be estimated by the full width at half maximum (FWHM) of a kernel line and lies within 10-20 km.

Further, the retrieval yields the profile of the a priori contribution which clearly describes how much of the ozone profile comes from the a priori guess and how much comes from the measurement. The right panel of Fig. 2 shows the mean a priori contribution in percent for night- and daytime observations (blue, respectively magenta). The a priori contributions are nearly identical, and GROMOS measures with equivalent quality for night and day. Please note that the a priori contribution is around zero at altitudes from 20 to $45 \mathrm{~km}$. Thus the retrieved ozone values at these altitudes are solely based on the measured ozone line spectrum. The error assessment of the mean ozone profiles is difficult. The systematic error is around $7 \%$ as mentioned before. For the determination of the diurnal ozone variation, a constant systematic error would play no role at all. On the other hand, it seems to be impossible to make an assumption about a possible systematic error, which may vary with local solar time. However we find no 

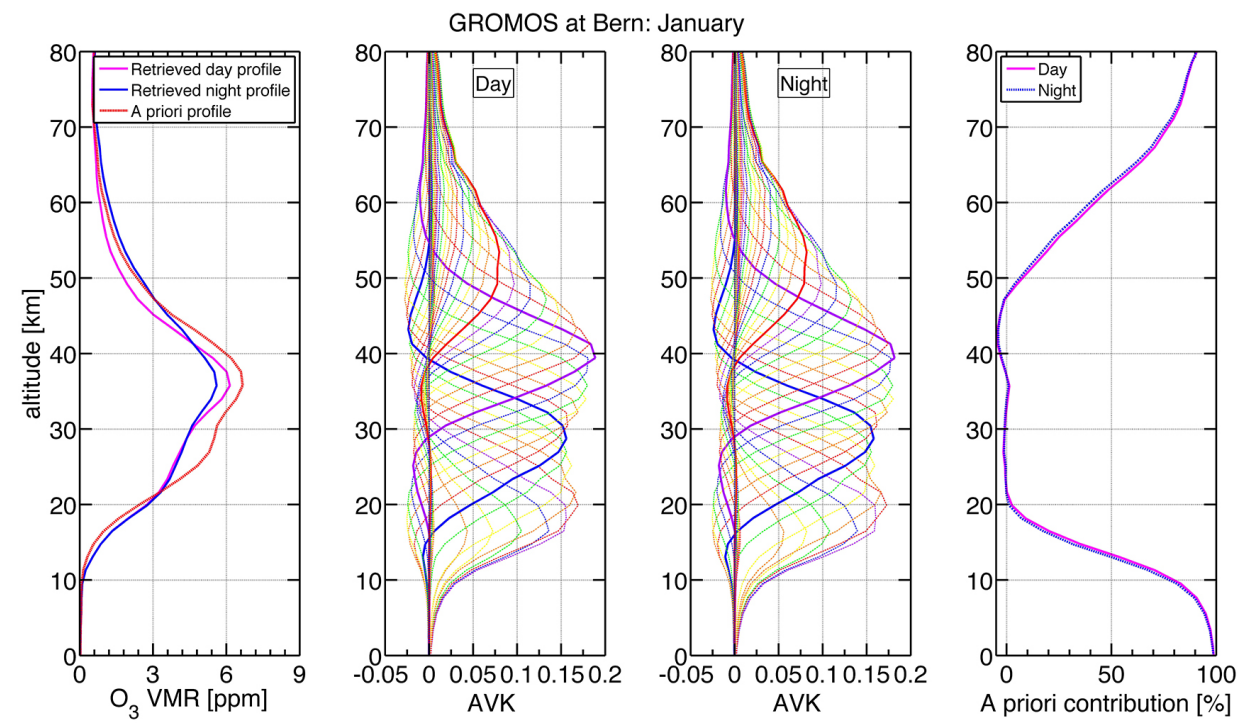

Figure 2. The left panel shows the averaged GROMOS daytime (magenta) and nighttime (blue) profiles for January 2010 as well as the a priori profile (red). The two middle panels depict the daytime and nighttime averaging kernel (AVK) matrices. The a priori contribution is shown in the right panel for daytime (magenta) and nighttime (blue).

indication for such a variable systematic error in the GROMOS measurements.

The model data are interpolated onto the same vertical pressure grid as the ozone profiles of GROMOS. All ozone data presented are ozone volume mixing ratios $\left(\mathrm{O}_{3} \mathrm{VMR}\right)$.

\subsection{Definition of the the diurnal ozone variation}

The diurnal ozone variation at the location of Bern for GROMOS and models were calculated by

$\Delta \mathrm{O}_{3, \text { abs }}=\mathrm{O}_{3}-\mathrm{O}_{3, \text { midnight }}$
$\Delta \mathrm{O}_{3, \text { rel }}=\frac{\mathrm{O}_{3}-\mathrm{O}_{3, \text { midnight }}}{\mathrm{O}_{3, \text { midnight }}}$,

where the $\mathrm{O}_{3}$,midnight is taken by monthly averaging the ozone values of the time interval 22:30 to 01:30 LST at each pressure level. For the climatology of diurnal ozone variations of GROMOS, the error of the mean values including the natural variability is estimated by the standard deviation $\sigma_{i}$ from 17 years of measurements, where the index $i=1: 24$ gives the hourly time bin $i$ based on LST. Model simulations from WACCM and HAMMONIA included one model year (representative of all years of observation). Interannual variation of the diurnal ozone cycle is studied only by using GROMOS data.

\subsection{Effect of AVK smoothing on the high-resolution model data}

The relatively low vertical resolution of ground-based microwave radiometers is often taken into account in comparison studies with other (higher resolution) instruments and models by means of the so-called kernel smoothing. This is usually done by convolving the high-resolution data with the averaging kernels of the low-resolution instrument. Most authors assume that the high-resolution profile is not affected by its own kernels and/or a priori profile (Tsou et al., 1995). In this simplified case the high-resolution profile is convolved with the AVKs of the low-resolution instrument. Calisesi et al. (2005) considered the limited resolution of both data sets, which is the correct method. However the method introduced by Calisesi et al. (2005) really needs time and good programming skills for the implementation.

For the aims of the present study, the simple approach of Tsou et al. (1995) is sufficient since the intercomparison of observation and models is not the focus of the present article. We decided not to smooth the high-resolution model data with the AVKs of GROMOS since the aim is to characterize the diurnal ozone variation and not to impose the limited resolution of radiometer measurements to high-resolution model data, in which case interesting features might be lost.

For one example of high-resolution WACCM data in July 2000, we show the effect of kernel smoothing. By means of Fig. 3 the reader can better judge which characteristics of the diurnal ozone variation are visible for the model and which characteristics are smoothed out by the ground-based microwave radiometer. Figure $3 \mathrm{a}$ shows the diurnal ozone variation simulated by WACCM in high resolution. Figure $3 \mathrm{~b}$ is the WACCM data convolved with the AVKs of GROMOS. An example of the AVKs of GROMOS is shown in the middle panel of Fig. 2. Figure $3 b$ would be the result if GROMOS observed the WACCM model atmosphere. It is evident that GROMOS cannot observe the thin descending red layer after sunrise at 04:00 LST in Fig. 3a. Further, the extreme values 

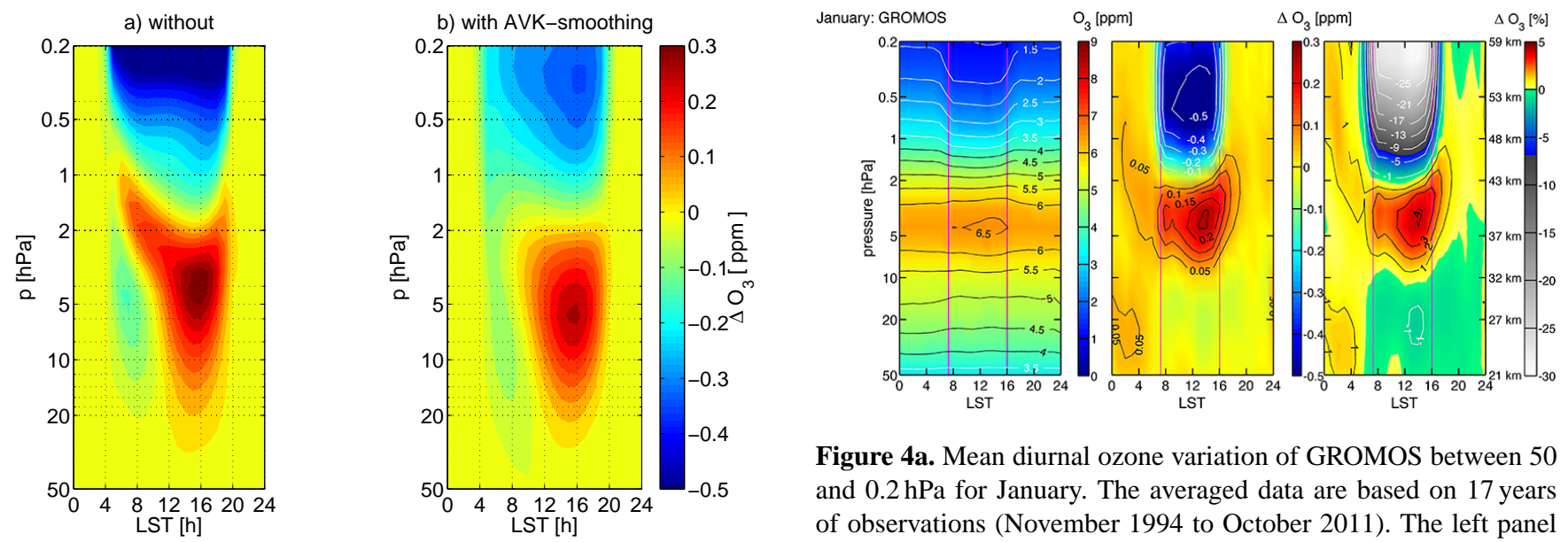

Figure 4a. Mean diurnal ozone variation of GROMOS between 50 and $0.2 \mathrm{hPa}$ for January. The averaged data are based on 17 years of observations (November 1994 to October 2011). The left panel shows the variation of ozone volume mixing ratio (VMR) as a function of local solar time (LST). The middle panel gives the absolute mean difference $\Delta O_{3}$, while the right panel shows the relative mean difference $\Delta \mathrm{O}_{3}$ in percent. Both absolute and relative mean differences are with respect to the mean nighttime ozone value (22:30 01:30 LST) of January. Magenta lines indicate a solar zenith angle of $90^{\circ}$.

are a bit reduced in the smoothed WACCM data of Fig. $3 b$. For example the maximum at 16:00 LST is a bit weaker and also lowered from about $4 \mathrm{hPa}$ to $6 \mathrm{hPa}$. On the other hand the height of the phase reversal (change from blue to red colour) is not changed at 14:00 LST by AVK smoothing, and it remains at about $2 \mathrm{hPa}$. However in the morning and late afternoon hours the height of the phase reversal is lowered by AVK smoothing.

In the following we only show the high-resolution model data, which are certainly a good motivation for the observers to improve the vertical resolution of their instruments and their retrieval techniques.

\section{Results on the diurnal ozone variation}

\subsection{GROMOS}

Figure 4a, 4b, 4c, and 4d give the mean diurnal ozone variations from 17 years of GROMOS measurements. Shown are January, April, July and October, which represent the seasons winter, spring, summer and autumn. Plotted are LST variations in ozone and diurnal variations $\Delta \mathrm{O}_{3 \text {,abs }}$ (Eq. 1) in absolute as well as $\Delta \mathrm{O}_{3 \text {,rel }}$ (Eq. 2) in relative units from 50 to $0.2 \mathrm{hPa}$. Magenta lines indicate a solar zenith angle (SZA) of $90^{\circ}$, which roughly corresponds to sunrise and sunset.

The diurnal ozone variation is already obvious in the plots of mean ozone at the left-hand-side panels of Fig. 4a, 4b, 4c, and $4 \mathrm{~d}$. As expected, mesospheric ozone is decreased by $25-$ $30 \%$ during daytime due to the intense solar UV radiation (photodissociation of ozone, Reaction R4) and the smaller recombination rate of ozone (Reaction R2) at upper altitudes (Allen et al., 1984).

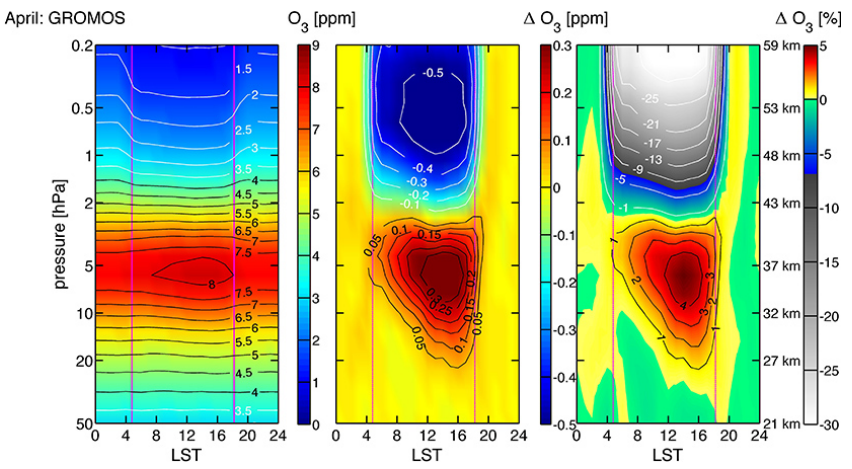

Figure 4b. Same as Fig. 4a but for the month of April.

The mean diurnal variation for April (Fig. 4b) is in agreement with Zommerfelds et al. (1989), who also see a daytime decrease in ozone of $-30 \%$ (compared to nighttime ozone) for April 1987 at $56 \mathrm{~km}$ above Bern. Ricaud et al. (1996) used data from the MLS instrument onboard the UARS satellite and compared the results to two photochemical models and ground-based microwave measurements from Bordeaux observatory ( $44.8^{\circ} \mathrm{N}$, France) and Table Mountain $\left(34.4^{\circ} \mathrm{N}\right.$, California). The diurnal variation of mesospheric ozone from models and observations agreed within $10 \%$. Schneider et al. (2005) obtained a decrease of $-35 \%$ for lower mesospheric ozone at $55 \mathrm{~km}$ altitude during daytime.

A phase reversal of the diurnal ozone variation occurs at about $2 \mathrm{hPa}$ in Fig. 4a, 4b, 4c, and 4d, where the bluish colours of decreased daytime ozone in the mesosphere change to reddish colours of increased daytime ozone in the stratosphere. In April and July, the phase reversal height is a bit lower than in January and October. Around $5 \mathrm{hPa}$, an 


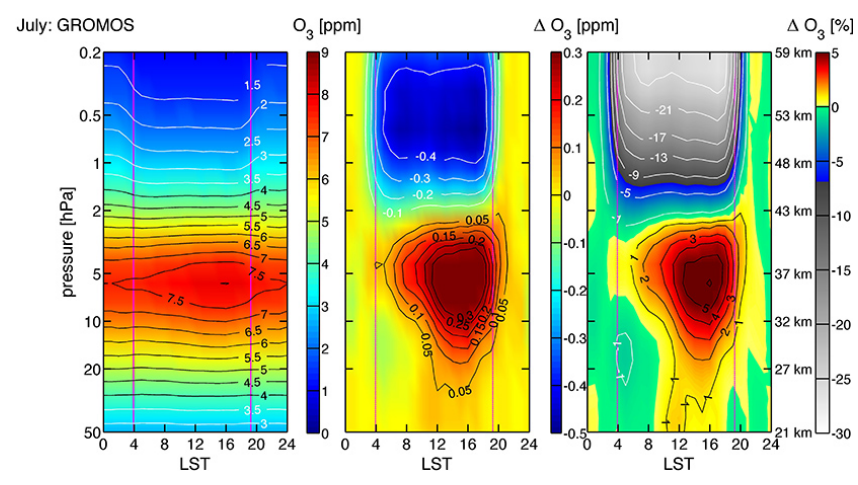

Figure 4c. Same as Fig. 4a but for the month of July.

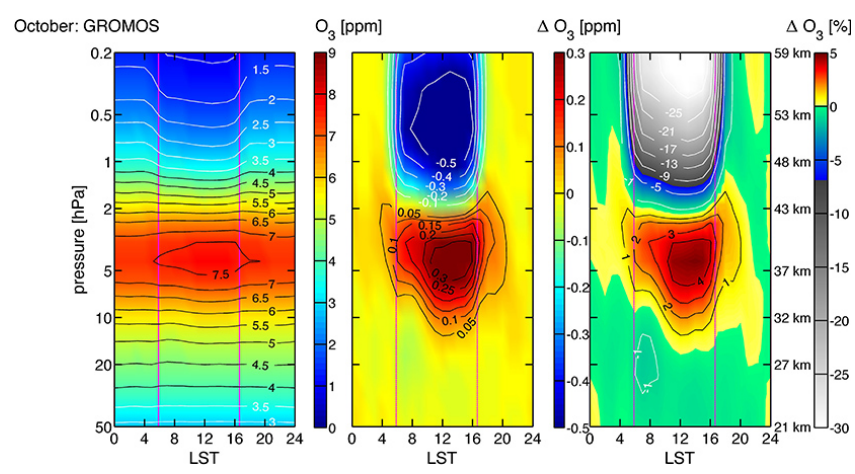

Figure 4d. Same as Fig. 4a but for the month of October.

afternoon maximum of approximately $4 \%$ in winter and $6 \%$ in summer can be seen around 3 p.m. in Fig. 4a, 4b, 4c, and $4 d$. Our afternoon ozone maxima are slightly higher than those of Parrish et al. (2013), who found afternoon maxima of $2-3 \%$ with respect to midnight ozone above Mauna Loa $\left(19.5^{\circ} \mathrm{N}\right.$, Hawaii).

Haefele et al. (2008) also found that, above $2 \mathrm{hPa}$, ozone strongly decreases during daytime while below $2 \mathrm{hPa}$ a daytime enhancement in ozone is observed. They attributed the phase reversal to the $[\mathrm{O}] /\left[\mathrm{O}_{3}\right]$ ratio, which is inversely dependent on air density. Thus the partitioning of odd oxygen changes from $\mathrm{O}_{3}$ in the stratosphere to $\mathrm{O}$ in the mesosphere during daytime. After sunset the atomic oxygen in the mesosphere rapidly recombines with molecular oxygen under formation of ozone. For further explanation of the physics and chemistry of the diurnal ozone variation, the reader is referred to Haefele et al. (2008) and Schanz et al. (2014).

The ozone variation in the stratosphere and lower mesosphere observed by Haefele et al. (2008) is in accordance with the model simulations which they carried out. They also discussed the seasonal dependence of the diurnal ozone variation by looking at March, June and September data. The diurnal ozone variation at $3 \mathrm{hPa}$ measured by the ozone microwave radiometer in Haefele et al. (2008) is stronger by a few percent compared to the present study. They only used 2-3 years of data for derivation of the seasonal behaviour in spring, summer and autumn. This may explain the superposed high-frequency oscillations in their results, which are possibly due to data outliers or intraseasonal variability. The advantage of our study is that we derived a smooth seasonal behaviour of the diurnal ozone variation from the 17 years of GROMOS measurements.

Contrary to photochemical model simulations (e.g. Herman, 1979; Pallister and Tuck, 1983), GROMOS does not show a decrease of stratospheric ozone after sunrise. Possibly this characteristic is invisible for GROMOS because of its relatively low vertical resolution. In addition the time window length of $2 \mathrm{~h}$, which was used for GROMOS may suppress the observation of the small dip in ozone after sunrise. Parrish et al. (2013) measured a small dip in stratospheric ozone (around $-1 \%$ ) after sunrise. The small dip in stratospheric ozone after sunrise was also observed by the SMILES experiment at the International Space Station (Fig. 5a in Sakazaki et al. (2013)).

It is likely that the vertical resolution of the Mauna Loa radiometer is higher than the resolution of GROMOS. The vertical resolution slightly depends on the spectral resolution of the ozone line measurement, the elevation angle of the antenna, and the retrieval parameters, which depend on the data quality. Because of the very low tropospheric opacity on Mauna Loa, the measurement and the retrieval can be performed with a higher vertical resolution compared to GROMOS. Besides this small discrepancy, Fig. 4a, 4b, 4c, and 4d are in a good agreement with previous photochemical simulations and observations of the diurnal ozone variation. An upgrade of the GROMOS spectrometer was recently carried out so that in future GROMOS might be able to observe with a higher vertical resolution (e.g. $8 \mathrm{~km}$ instead of $10 \mathrm{~km}$ ).

\subsection{Comparison between GROMOS and models}

Figure 5a and 5b show the outputs from WACCM and HAMMONIA for July and can be compared to Fig. 4c of GROMOS. July has been chosen for the comparison since the stratosphere in summer is less disturbed compared to winter when planetary wave activity is high. Further, a smaller year-to-year variation is found in summer measurements than for winter where dynamical processes are strong (planetary waves). It is important to note that, as mentioned in Sects. 2.2 and 2.3, both models use the chemistry module MOZART. Other components of the models such as dynamical cores and physical parameterization are different.

Models and GROMOS agree well for the diurnal ozone variation in July. They show similar patterns of the diurnal variation with similar amplitudes. Some differences are pointed out: (1) the phase reversal height (where decreased daytime ozone in the mesosphere changes to increased daytime ozone in the stratosphere) is slightly different. While GROMOS sees the phase reversal at around $2 \mathrm{hPa}$, both models show the phase reversal at $1.5 \mathrm{hPa}$. Just after sunrise the phase reversal occurs even higher at $1 \mathrm{hPa}$, but this 


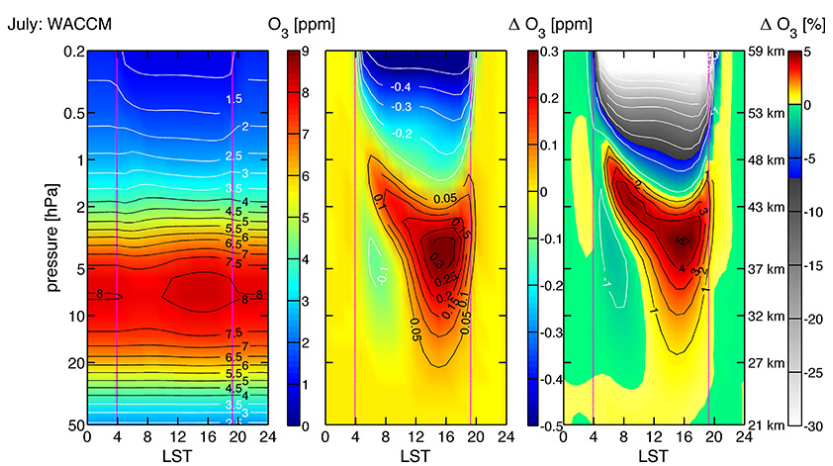

Figure 5a. Mean diurnal ozone variation of WACCM between 50 and $0.2 \mathrm{hPa}$ for July. The left, middle and right panel are described in Fig. 4a.

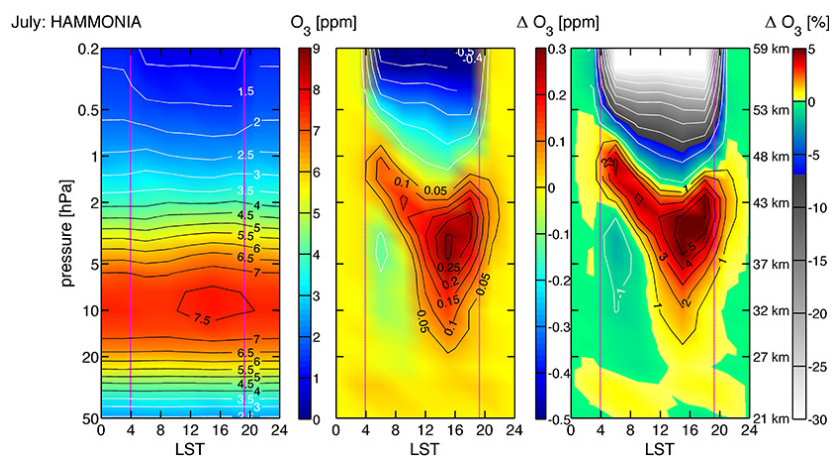

Figure 5b. Mean diurnal ozone variation of HAMMONIA between 50 and $0.2 \mathrm{hPa}$ for July. The left, middle and right panel are described in Fig. 4a.

characteristic would be lowered down to $1.5 \mathrm{hPa}$ if kernel smoothing were applied to the high-resolution model output (as shown before in Fig. 3). (2) The afternoon maximum appears at a slightly higher altitude in the models than in GROMOS observations (around $3 \mathrm{hPa}$ ). (3) WACCM and HAMMONIA both show a phase progression in local time (e.g. downward motion of the red layer after sunrise), which is partly hidden in the GROMOS observation because of the insufficient vertical resolution of GROMOS. As well, the dip of ozone after sunrise at $5 \mathrm{hPa}$ seen in the models is possibly smoothed out in the GROMOS measurements.

The downward phase progression in the model results of WACCM and HAMMONIA (Fig. 5a and 5b) from around $1 \mathrm{hPa}$ in the morning (around $6 \mathrm{a} . \mathrm{m}$.) to approximately $3 \mathrm{hPa}$ in the afternoon (around 4 p.m.) has been noted before in thermal tides: Huang et al. (2010b) derived diurnal temperature variations (migrating tides) from SABER on TIMED. On the other hand the rising sun may directly cause a descending ozone layer by means of photodissociation (Fig. 5a and 5b). The photochemical box models already showed a dip of mid-stratospheric ozone after sunrise indicating that ozone photochemistry together with the diurnal change of the solar zenith angle can explain many characteristics of Fig. 5a
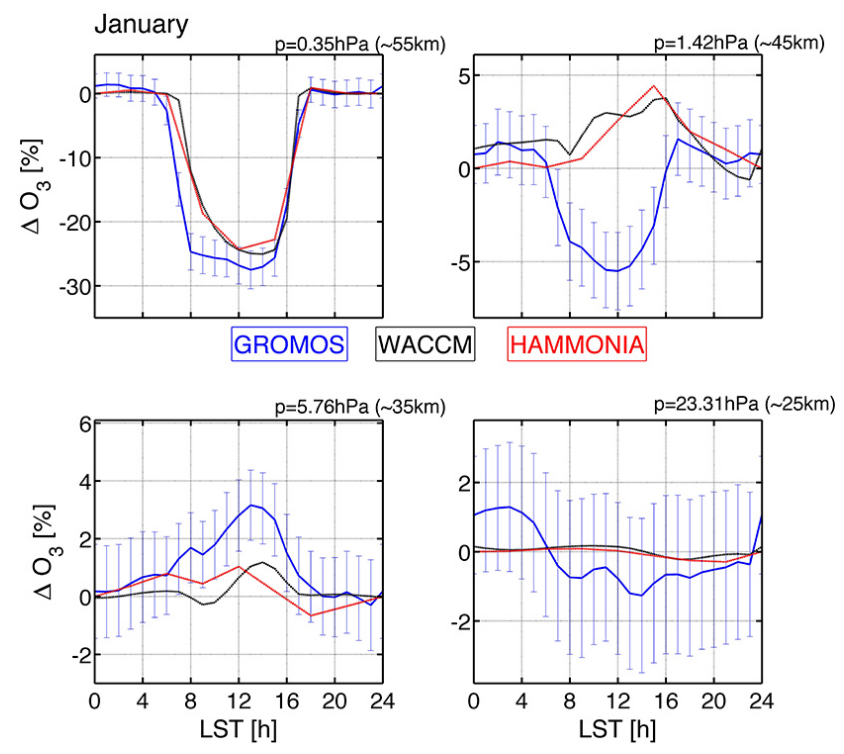

Figure 6a. Relative mean differences for four different pressure levels in January. GROMOS is given by the blue line, while WACCM is given in black and HAMMONIA in red. The error bars denote the mean standard deviation of GROMOS.

and $5 \mathrm{~b}$. Around sunset, there is an increase of ozone in the stratopause region and also at higher altitudes after sunset. This has been discussed for the mesosphere by Marsh et al. (2003) and attributed to the temperature-dependent production rate of $\mathrm{HO}_{\mathrm{x}}$.

Figure $6 \mathrm{a}$ and $6 \mathrm{~b}$ show the diurnal ozone variations for mean January and July on four pressure levels (approx. at $55,45,35$ and $25 \mathrm{~km}$ ). GROMOS is given in blue (together with standard deviation $\sigma_{i}$ ), and the models are given in black (WACCM) and red (HAMMONIA). At $55 \mathrm{~km}$, the daytime amplitudes from WACCM and HAMMONIA agree well with those of GROMOS in January. For July, the amplitude of all data sets is found to be in very good agreement (about $25 \%$ decrease of daytime ozone).

Figure $6 \mathrm{a}$ and $6 \mathrm{~b}$ are in a good agreement with Fig. 4 in Sakazaki et al. (2013), who compared satellite observations $\left(10^{\circ} \mathrm{S}-10^{\circ} \mathrm{N}\right)$ of SMILES/ISS to model simulations (MIROC3.2-CTM, SD-WACCM). Sakazaki et al. (2013) obtained an excellent agreement between the simulated and observed diurnal ozone variation at all altitudes from 24 to $54 \mathrm{~km}$ (absolute differences $<0.05 \mathrm{ppm}$ ). Dikty et al. (2010) looked at daytime ozone variations from the HAMMONIA model output and SABER onboard the TIMED satellite. They reported a good agreement between HAMMONIA and SABER daytime ozone variations in the mesosphere. Beig et al. (2012) examined diurnal variations of ozone in the tropics above $1 \mathrm{hPa}$ from HAMMONIA and HALOE onboard UARS. They noted that the amplitude of diurnal ozone variation derived from HALOE is slightly lower than HAMMONIA. Generally we see that the diurnal variation in lower 

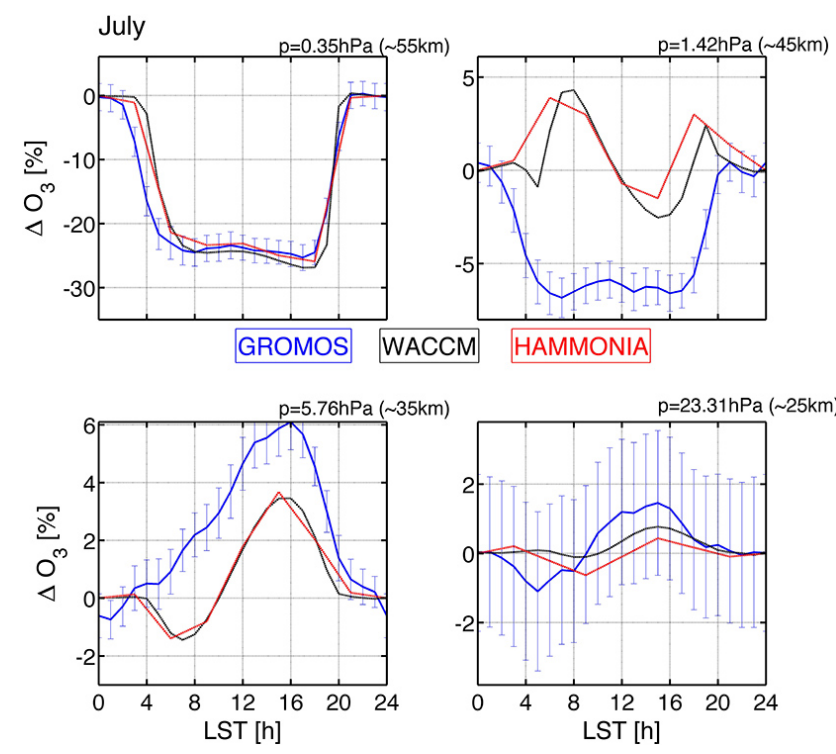

Figure 6b. Same as Fig. 6a but for the month of July.

mesospheric ozone is well captured by models, ground-based and space-based observations.

At $1.42 \mathrm{hPa}$, GROMOS measures a decrease in ozone during daytime ( -5 to $-7 \%)$, while models already switched to a slight increase of daytime ozone. The Mauna Loa microwave instrument (March average of 1996-2012) also shows a decrease of $-5 \%$ at $1.3 \mathrm{hPa}$, supporting our measurements (Parrish et al., 2012). However we should keep in mind that both radiometers have a lower vertical resolution than the models.

For $5.8 \mathrm{hPa}$ in January, an afternoon maximum (of approx. $3 \%$ ) is found at 3 p.m. WACCM and HAMMONIA do not show a relevant diurnal variation at this pressure level (amplitude $<1 \%$ ). The Mauna Loa microwave instrument also measures an amplitude of approx. $+3 \%$, again for March. The phase is shifted by about $2 \mathrm{~h}(3 \mathrm{p} . \mathrm{m}$. for the radiometer at Mauna Loa and 1 p.m. for GROMOS in Bern). For July, the diurnal amplitude of GROMOS increases up to $+6 \%$ around 4 p.m. The models also show a daily variation with an afternoon maximum of $+3 \%$ at 4 p.m. While for January models are mostly within the GROMOS $\sigma$-bars, they do not overlap for July at $5.8 \mathrm{hPa}$.

For $23 \mathrm{hPa}, \sigma$ values are larger than the diurnal ozone amplitudes which do not exceed $1 \%$ for all data sets. Hence, if there is a diurnal cycle in the lower stratosphere, amplitudes are very small (at midlatitudes). GROMOS shows a small increase of lower stratospheric ozone at daytime in July, while Sakazaki et al. (2013) presented a small decrease of lower stratospheric ozone in the late afternoon at the Equator based on ISS/SMILES observations and SD-WACCM simulations.

In summary the intercomparison of GROMOS with WACCM and HAMMONIA shows a good agreement if we keep the effect of kernel smoothing in mind. Some features
- such as the descending thin layer after sunrise which are seen by the models - are not resolved by GROMOS. The low vertical resolution of GROMOS also leads to a small downward shift of the phase reversal height. It also seems that the small dip in ozone after sunrise in the stratosphere, which is present in all models, including the photochemical box models, is smoothed out by the low vertical resolution of GROMOS. So the small dip in ozone after sunrise can be a benchmark for further improvement of the radiometer and the retrieval technique.

On the other hand, the observations of ground-based microwave radiometers still remain the unique benchmark for the model simulations and satellite observations. The diurnal ozone variation observed by GROMOS agrees well with reports from other ground-based microwave radiometers and with the results of Sakazaki et al. (2013) at altitudes beyond $30 \mathrm{~km}$. Thus we are now in good shape for a detailed study of the mean seasonal and interannual variability in the diurnal ozone variation as monitored by GROMOS since 1994.

\section{Seasonal behaviour of the diurnal ozone variation}

Figure 7 shows the diurnal ozone variation as a function of month (January to December) in the stratosphere at $5.76 \mathrm{hPa}$. The results from GROMOS (Fig. 7a) are compared to the WACCM output (Fig. 7b). Magenta lines indicate a solar zenith angle of $90^{\circ}$, which roughly corresponds to the time of sunrise and sunset.

The afternoon maximum is clearly visible in both the observation and model for all months. They further agree on a stronger afternoon maximum in summer than in winter. GROMOS peaks in July with $+6 \%$ and WACCM peaks from May to August with $+3 \%$. The small ozone dip after sunrise is present in WACCM over the whole year with extreme values less than $-1 \%$ at the end of January and from April to July. GROMOS does not see the dip after sunrise because of its low vertical resolution. However GROMOS also shows like WACCM that the accumulation of ozone is delayed to the noon and afternoon hours in all seasons. Further, GROMOS shows some intraseasonal variability, for example, stronger afternoon maxima at the beginning of May and July.

Figure 8 is as Fig. 7 but for the lower mesosphere at $0.35 \mathrm{hPa}$. The diurnal ozone variation agrees well for GROMOS and WACCM. GROMOS has stronger bluish colours than WACCM in the afternoon hours around March and November where the daytime decrease of ozone is up to $-30 \%$. WACCM also shows a strong ozone decrease in the afternoon hours. WACCM has a bit more intraseasonal variability than GROMOS, which can be due to the fact that only 1 year was taken for the WACCM plot, while 17 years were averaged for the GROMOS plot.

It is interesting that GROMOS shows lighter bluish colours at noon during the summer season compared to the 

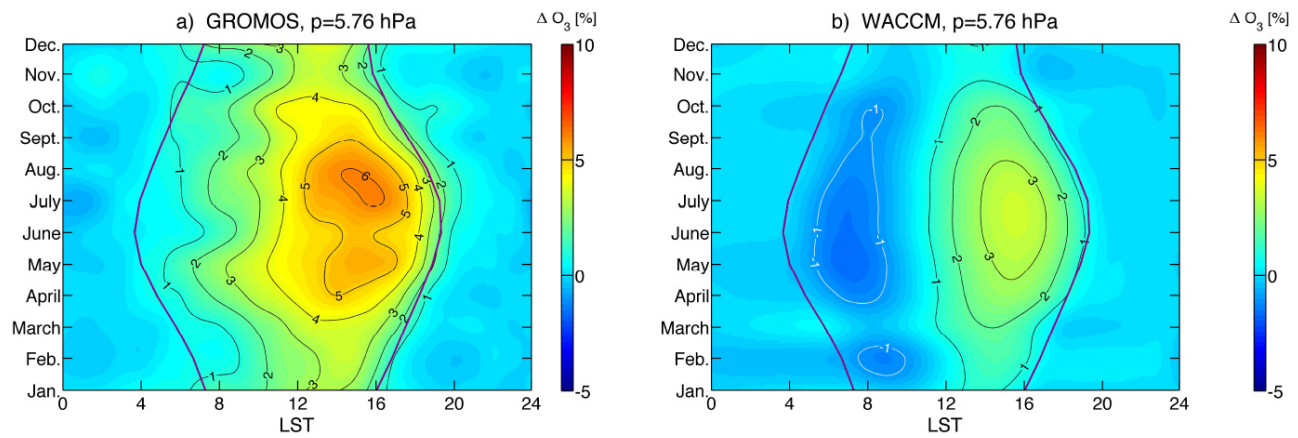

Figure 7. Mean seasonal behaviour of the diurnal ozone variation for the pressure level $5.76 \mathrm{hPa}$ in the stratosphere. (a) shows the observational result of the ground-based microwave radiometer GROMOS at Bern. (b) shows the simulation result of the model WACCM at a grid point near Bern.
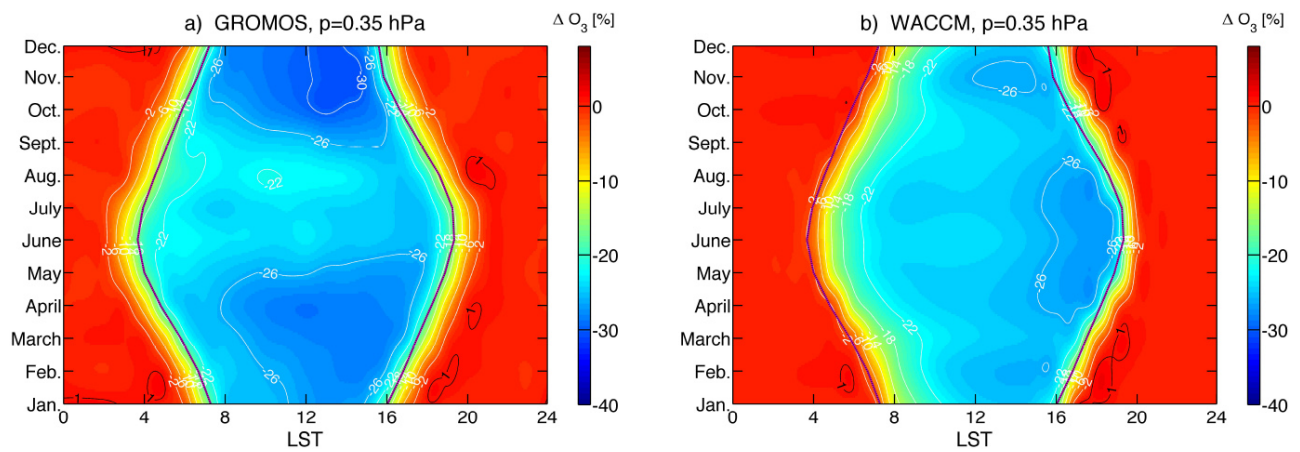

Figure 8. Same as Fig. 7 but for the pressure level $0.35 \mathrm{hPa}$ in the mesosphere.

other seasons. Atmospheric composition changes, diurnal changes in temperature and of course the seasonal variation of the solar zenith angle are possible reasons for the observed seasonal and intraseasonal variations.

\section{Interannual variation of the diurnal ozone variation}

We used the 17 years of GROMOS measurements to study the interannual variability in the diurnal ozone variation. Figure 9 presents the results for the two pressure levels $5.76 \mathrm{hPa}$ and $0.35 \mathrm{hPa}$ as in the previous section. The left-hand-side panel shows the result for the diurnal variation of stratospheric ozone. It is interesting to see that the accumulation of ozone until late afternoon slightly changes from year to year. In addition, some years show enhanced intraseasonal variability (several horizontal red stripes within 1 year, e.g. 2005 or 2006). A reason for the intraseasonal variability in winter could be the variability of the polar vortex, which is the main cause for intraseasonal variability of atmospheric composition at Bern during winter (Studer et al., 2012; Hocke et al., 2013). The intraseasonal variability in the summer stratosphere is a surprise. Atmospheric composition changes might be an explanation. We find the diurnal amplitude to be larger in summer than in winter at $5.76 \mathrm{hPa}$ and smaller in summer than in winter at $0.35 \mathrm{hPa}$. Nevertheless, Fig. 9 shows that there are strong interannual variations in both stratosphere and mesosphere.

There is a strong decrease in GROMOS daytime ozone in winter 2006 in the mesosphere (at $0.35 \mathrm{hPa}$ ). The large negative values during daytime in winter 2006 might be linked to the major sudden stratospheric warming (SSW) described by Manney et al. (2009). During a SSW, the atmospheric composition of the stratosphere is changed by meridional and vertical transport of air masses.

A possible reason for the anomaly in summer 2000 is the temperature dependence of ozone. As mentioned in the introduction, ozone and temperature perturbations are anticorrelated in the upper stratosphere. This is illustrated in Fig. 10. It shows the day-night differences of stratospheric ozone from GROMOS and temperature (moving average over 12 months) using data from ECMWF (European Centre for Medium-Range Weather Forecast) (2.5 to $5.5 \mathrm{hPa}$ ). The correlation coefficient is $R=-0.75( \pm 0.07)$ at the $95 \%$ confidence level. The anomaly in temperature and ozone (small $\Delta T$ and large $\Delta \mathrm{O}_{3}$ ) of 2000 in Fig. 10 might be related to the El Niño-Southern Oscillation (ENSO) 1997/1998. Pedatella and Liu (2012) investigated the migrating and non-migrating variability of tides in the mesosphere and lower thermosphere due to the ENSO based on WACCM simulations. They found that the ENSO-driven variability in the migrating 

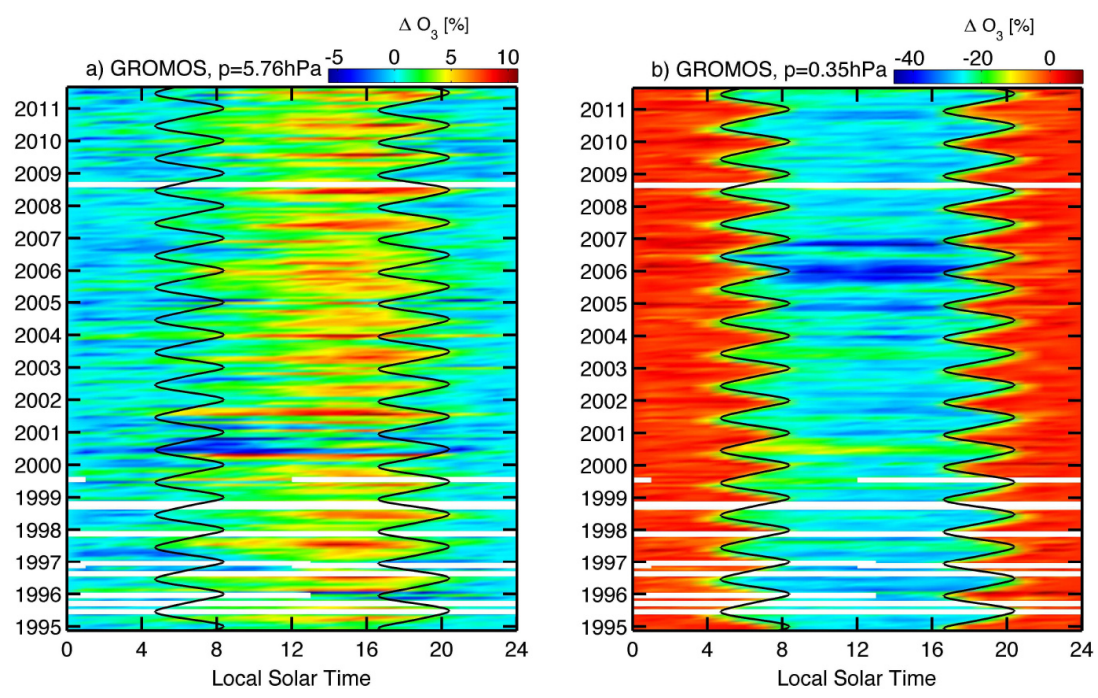

Figure 9. Interannual variability of the diurnal ozone variation from Nov 1994 to Oct 2011. (a) shows the interannual variability at $5.76 \mathrm{hPa}$ in the stratosphere. (b) depicts the interannual variability at $0.35 \mathrm{hPa}$ in the lower mesosphere.

noon-midnight: $\Delta \mathrm{O}_{3}$ of GROMOS, $\Delta \mathrm{T}[\mathrm{K}]$ of ECMWF at Bern, $\mathrm{p}=2.5-5.5 \mathrm{hPa}$

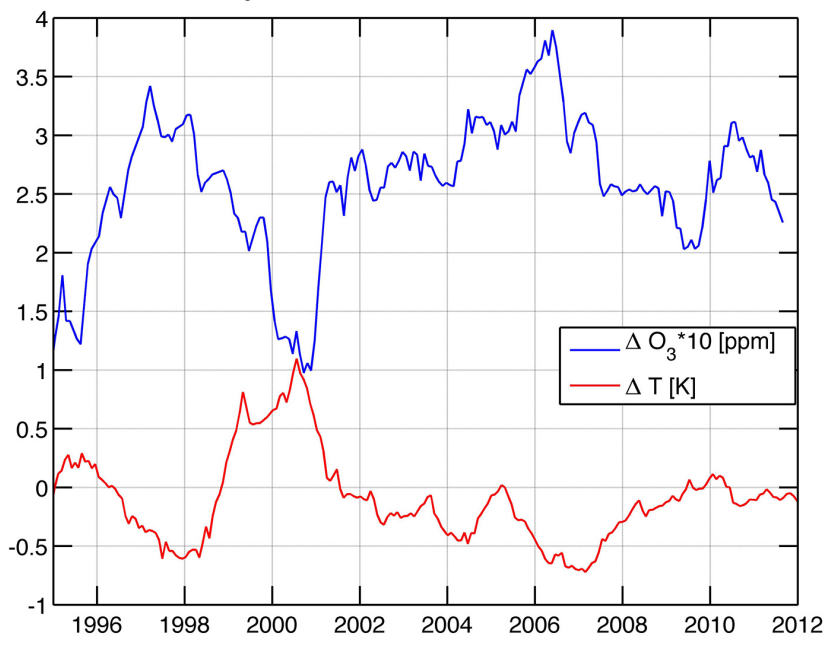

Figure 10. Difference of noon value minus midnight value. The red line shows this difference in case of temperature from ECMWF operational reanalysis (12:00 UT minus 00:00 UT). The blue line shows the difference in case of ozone from GROMOS at pressure level $4 \pm 1.5 \mathrm{hPa} . \Delta T$ and $\Delta \mathrm{O}_{3}$ are anticorrelated with $R=-0.75$.

diurnal tide is found to be primarily due to changes in the tropospheric forcing (Pedatella and Liu, 2013). We suppose that the increase of temperature during daytime leads to a reduced accumulation of ozone during daytime.

We are quite far away from understanding the interannual variability of the diurnal ozone variation. The GROMOS observations indicate their existence, and it is reasonable that the interannual variability of atmospheric composi- tion, dynamics and thermal state of the middle atmosphere can change the characteristics of the diurnal ozone variation.

\section{Conclusions}

Stratospheric and mesospheric ozone, measured by the radiometer GROMOS from 17 years of observation, have been analysed in order to study the diurnal ozone variation from 50 to $0.2 \mathrm{hPa}(\sim 21-59 \mathrm{~km})$. A climatology of the diurnal ozone variation above Bern, Switzerland, is presented. The observational results from GROMOS have been compared with simulation outputs from the high-resolution chemistry climate models WACCM and HAMMONIA.

We find that observation and models are generally consistent. Amplitudes in the mesosphere are of about $-25 \%$, and in the stratosphere an afternoon maximum of about $+4 \%$ is present. The phase reversal from decreased daytime ozone at mesospheric altitudes to increased daytime ozone in the stratosphere occurs in the model simulations at $1.5 \mathrm{hPa}$ and in the GROMOS measurements at $2 \mathrm{hPa}$. However the vertical resolution of GROMOS is about $10 \mathrm{~km}$ so that GROMOS only provides a rough estimate of the phase reversal height.

We presented for the first time the complete seasonal variability of the diurnal ozone variation. The long-term climatology derived from the GROMOS measurements at Bern shows

(1) a larger relative diurnal amplitude during summer months for the stratosphere. For the pressure level of $5.8 \mathrm{hPa}$, the amplitude is $+6 \%$ in summer, while for winter the amplitude is of the order of $+3 \%$.

(2) a smaller relative diurnal amplitude during summer compared to winter in the mesosphere. At $0.35 \mathrm{hPa}$, the 
diurnal amplitude in winter is up to $-30 \%$, while for summer it is around $-22 \%$.

Opposed to the latter result, WACCM outputs show a larger mesospheric amplitude during summer compared to winter. A strong interannual variability of the diurnal ozone variation shows up in the 17 years of GROMOS observations. Indications are found that temperature-dependent ozone photochemistry may influence the diurnal variation of stratospheric ozone. Our observational results suggest that the intraseasonal, seasonal and interannual variability of the diurnal ozone variation should be considered when correcting diurnal sampling effects in satellite data to improve trend estimates of stratospheric ozone. Therefore, ongoing effort is needed in order to improve our knowledge of the diurnal ozone variation in the stratosphere. For these reasons, scientists from various observation and model communities have built up a team at the International Space Science Institute (ISSI) with the goal of tackling the still unresolved subject of "Characterizing Diurnal Variations of Ozone for Improving Ozone Trend Estimates".

Acknowledgements. This research was funded by the Swiss National Science Foundation SNF under grant no. 200020-134613. The research leading to these results has received funding from the European Community's Seventh Framework Programme ([FP7/2007-2013]) under grant agreement no. 284421 (see Article II.30. of the grant agreement). We thank the MLS team for the ozone data used in this study, which was retrieved from the NASA Goddard Space Flight Center. This work was further supported by the International Space Science Institute (ISSI) in Bern, Switzerland. We would like to thank members of the first workshop held at ISSI on the subject "Characterizing Diurnal Variations of Ozone for Improving Ozone Trend Estimates" for discussions and inputs (http://www.issibern.ch/teams/ozonetrend/).

Edited by: M. Weber

\section{References}

Achatz, U., Grieger, N., and Schmidt, H.: Mechanisms controlling the diurnal solar tide: Analysis using a GCM and a linear model, J. Geophys. Res. Space Phys., 113, A08303, doi:10.1029/2007JA012967, 2008.

Allen, M., Lunine, J. I., and Yung, Y. L.: The vertical distribution of ozone in the mesosphere and lower thermosphere, J. Geophys. Res. Atmos., 89, 4841-4872, doi:10.1029/JD089iD03p04841, 1984.

Barnett, J. J., Houghton, J. T., and Pyle, J. A.: The temperature dependence of the ozone concentration near the stratopause, Q. J. Roy. Meteorol. Soc., 101, 245-257, doi:10.1002/qj.49710142808, 1975.

Beig, G., Fadnavis, S., Schmidt, H., and Brasseur, G. P.: Intercomparison of 11-year solar cycle response in mesospheric ozone and temperature obtained by HALOE satellite data and HAMMONIA model, J. Geophys. Res. Atmos., 117, D00P10, doi:10.1029/2011JD015697, 2012.
Bhartia, P. K., McPeters, R. D., Flynn, L. E., Taylor, S., Kramarova, N. A., Frith, S., Fisher, B., and DeLand, M.: Solar Backscatter UV (SBUV) total ozone and profile algorithm, Atmos. Meas. Tech., 6, 2533-2548, doi:10.5194/amt-6-2533-2013, 2013.

Calisesi, Y., Werli, H., and Kaempfer, N.: Midstratospheric ozone variability over Bern related to planetary wave activity during the winters 1994-1995 to 1998-1999, J. Geophys. Res., 106, 79037916, 2001.

Calisesi, Y., Soebijanta, V. T., and van Oss, R.: Regridding of remote soundings: Formulation and application to ozone profile comparison, J. Geophys. Res. (Atmospheres), 110, D23306, doi:10.1029/2005JD006122, 2005.

Chang, L., Palo, S., Hagan, M., Richter, J., Garcia, R., Riggin, D., and Fritts, D.: Structure of the migrating diurnal tide in the Whole Atmosphere Community Climate Model (WACCM), Adv. Space Res., 41, 1398-1407, doi:10.1016/j.asr.2007.03.035, 2008.

Chapman, S.: A theory of upper-atmospheric ozone, Mem. Roy. Meteorol. Soc., 3, 103-125, 1930.

Connor, B. J., Siskind, D. E., Tsou, J. J., Parrish, A., and Remsberg, E. E.: Ground-based microwave observations of ozone in the upper stratosphere and mesosphere, J. Geophys. Res. Atmos., 99, 16757-16770, doi:10.1029/94JD01153, 1994.

Craig, R. A. and Ohring, G.: The Temperature Dependence of Ozone Radiational Heating Rates in the Vicinity of the Mesopeak., J. Atmos. Sci., 15, 59-62, doi:10.1175/15200469(1958)015<0059:TTDOOR>2.0.CO;2, 1958.

Dikty, S., Schmidt, H., Weber, M., von Savigny, C., and Mlynczak, M. G.: Daytime ozone and temperature variations in the mesosphere: a comparison between SABER observations and HAMMONIA model, Atmos. Chem. Phys., 10, 8331-8339, doi:10.5194/acp-10-8331-2010, 2010.

Dumitru, M. C., Hocke, K., Kaempfer, N., and Calisesi, Y.: Comparison and validation studies related to ground-based microwave observations of ozone in the stratosphere and mesosphere, J. Atmos. Solar-Terr. Phys., 68, 745-756, 2006.

Eriksson, P., Jiménez, C., and Buehler, S. A.: Qpack, a general tool for instrument simulation and retrieval work, J. Quant. Spectrosc. Radiat. Transf., 91, 47-64, doi:10.1016/j.jqsrt.2004.05.050, 2005.

Eriksson, P., Buehler, S. A., Davis, C. P., Emde, C., and Lemke, O.: ARTS, the atmospheric radiative transfer simulator, Version 2, J. Quant. Spectrosc. Radiat. Transfer., 112, 1551-1558, doi:10.1016/j.jqsrt.2011.03.001, 2011.

Flury, T., Hocke, K., Haefele, A., Kämpfer, N., and Lehmann, R.: Ozone depletion, water vapor increase, and PSC generation at midlatitudes by the 2008 major stratospheric warming, J. Geophys. Res., 114, D18302, doi:10.1029/2009JD011940, 2009.

Garcia, R. R., Marsh, D. R., Kinnison, D. E., Boville, B. A., and Sassi, F.: Simulation of secular trends in the middle atmosphere, 1950-2003, J. Geophys. Res. Atmos., 112, D09301, doi:10.1029/2006JD007485, 2007.

Haefele, A., Hocke, K., Kämpfer, N., Keckhut, P., Marchand, M., Bekki, S., Morel, B., Egorova, T., and Rozanov, E.: Diurnal changes in middle atmospheric $\mathrm{H}_{2} \mathrm{O}$ and $\mathrm{O}_{3}$ : Observations in the Alpine region and climate models, J. Geophys. Res. Atmos., 113, D17303, doi:10.1029/2008JD009892, 2008.

Herman, J. R.: The response of stratospheric constituents to a solar eclipse, sunrise, and sunset, J. Geophys. Res. Ocean., 84, 37013710, doi:10.1029/JC084iC07p03701, 1979. 
Hocke, K., Kämpfer, N., Feist, D. G., Calisesi, Y., Jiang, J. H., and Chabrillat, S.: Temporal variance of lower mesospheric ozone over Switzerland during winter 2000/2001, Geophys. Res. Lett., 33, L09801, doi:10.1029/2005GL025496, 2006.

Hocke, K., Kämpfer, N., Ruffieux, D., Froidevaux, L., Parrish, A., Boyd, I., von Clarmann, T., Steck, T., Timofeyev, Y., Polyakov, A., and Kyrölä, E.: Comparison and synergy of stratospheric ozone measurements by satellite limb sounders and the groundbased microwave radiometer SOMORA, Atmos. Chem. Phys., 7, 4117-4131, doi:10.5194/acp-7-4117-2007, 2007.

Hocke, K., Studer, S., Martius, O., Scheiben, D., and Kämpfer, N.: A 20-day period standing oscillation in the northern winter stratosphere, Ann. Geophys., 31, 755-764, doi:10.5195/angeo31-755-2013, 2013.

Huang, F. T., Mayr, H. G., Russell, J. M., Mlynczak, M. G., and Reber, C. A.: Ozone diurnal variations and mean profiles in the mesosphere, lower thermosphere, and stratosphere, based on measurements from SABER on TIMED, J. Geophys. Res. Space Phys., 113, A04307, doi:10.1029/2007JA012739, 2008.

Huang, F. T., Mayr, H. G., Russell, J. M., and Mlynczak, M. G.: Ozone diurnal variations in the stratosphere and lower mesosphere, based on measurements from SABER on TIMED, J. Geophys. Res. Atmos., 115, D24308, doi:10.1029/2010JD014484, 2010a.

Huang, F. T., McPeters, R. D., Bhartia, P. K., Mayr, H. G., Frith, S. M., Russell, J. M., and Mlynczak, M. G.: Temperature diurnal variations (migrating tides) in the stratosphere and lower mesosphere based on measurements from SABER on TIMED, J. Geophys. Res. Atmos., 115, D16121, doi:10.1029/2009JD013698, 2010b.

Ingold, T., Peter, R., and Kämpfer, N.: Weighted mean tropospheric temperature and transmittance determination at milimeter-wave frequencies for ground-based application, Radio Sci., 33, 905918,1998

Jonsson, A. I., Fomichev, V. I., and Shepherd, T. G.: The effect of nonlinearity in $\mathrm{CO}_{2}$ heating rates on the attribution of stratospheric ozone and temperature changes, Atmos. Chem. Phys., 9, 8447-8452, doi:10.5194/acp-9-8447-2009, 2009.

Kinnison, D. E., Brasseur, G. P., Walters, S., Garcia, R. R., Marsh, D. R., Sassi, F., Harvey, V. L., Randall, C. E., Emmons, L., Lamarque, J. F., Hess, P., Orlando, J. J., Tie, X. X., Randel, W., Pan, L. L., Gettelman, A., Granier, C., Diehl, T., Niemeier, U., and Simmons, A. J.: Sensitivity of chemical tracers to meteorological parameters in the MOZART-3 chemical transport model, J. Geophys. Res. Atmos., 112, D20302, doi:10.1029/2006JD007879, 2007.

Lobsiger, E. and Künzi, K. F.: Night-time increase of mesospheric ozone mea269 sured with ground-based microwave radiometry, J. Atmos. Terr. Phys., 48, 1153-1158, 1986.

Manney, G. L., Harwood, R. S., MacKenzie, I. A., Minschwaner, K., Allen, D. R., Santee, M. L., Walker, K. A., Hegglin, M. I., Lambert, A., Pumphrey, H. C., Bernath, P. F., Boone, C. D., Schwartz, M. J., Livesey, N. J., Daffer, W. H., and Fuller, R. A.: Satellite observations and modeling of transport in the upper troposphere through the lower mesosphere during the 2006 major stratospheric sudden warming, Atmos. Chem. Phys., 9, 47754795, doi:10.5194/acp-9-4775-2009, 2009.
Marsh, D., Smith, A., and Noble, E.: Mesospheric ozone response to changes in water vapor, J. Geophys. Res. Atmos., 108 , doi:10.1029/2002JD002705, 2003.

Marsh, D. R., Garcia, R. R., Kinnison, D. E., Boville, B. A., Sassi, F., Solomon, S. C., and Matthes, K.: Modeling the whole atmosphere response to solar cycle changes in radiative and geomagnetic forcing, J. Geophys. Res. Atmos., 112, 4109, doi:10.1029/2006JD008306, 2007.

Pallister, R. C. and Tuck, A. F.: The diurnal variation of ozone in the upper stratosphere as a test of photochemical theory, Q. J. Roy. Meteorol. Soc., 109, 271-284, doi:10.1002/qj.49710946002, 1983.

Parrish, A., Boyd, I., Nedoluha, G., Bhartia, P. K., Frith, S., Connor, B., Bodeker, G., and Froidevaux, L.: Diurnal Variations of Stratospheric Ozone Measured by Ground-based Microwave Remote Sensing at the Mauna Loa NDACC site: Measurement Validation and Results, in: Quadrannial Ozone Symposium, Toronto, 2012.

Parrish, A., Boyd, I. S., Nedoluha, G. E., Bhartia, P. K., Frith, S. M., Kramarova, N. A., Connor, B. J., Bodeker, G. E., Froidevaux, L., Shiotani, M., and Sakazaki, T.: Diurnal variations of stratospheric ozone measured by ground-based microwave remote sensing at the Mauna Loa NDACC site: measurement validation and GEOSCCM model comparison, Atmos. Chem. Phys. Discuss., 13, 31855-31890, doi:10.5194/acpd-13-31855-2013, 2013.

Pedatella, N. M. and Liu, H.-L.: Tidal variability in the mesosphere and lower thermosphere due to the El Niño-Southern Oscillation, Geophys. Res. Lett., 39, L19802, doi:10.1029/2012GL053383, 2012.

Pedatella, N. M. and Liu, H.-L.: Influence of the El Niño Southern Oscillation on the middle and upper atmosphere, J. Geophys. Res. Space Phys., 118, 2744-2755, doi:10.1002/jgra.50286, 2013.

Pedatella, N. M., Liu, H.-L., Richmond, A. D., Maute, A. I., and Fang, T.-W.: Simulations of solar and lunar tidal variability in the mesosphere and lower thermosphere during sudden stratosphere warmings and their influence on the low-latitude ionosphere, J. Geophys. Res., 117, A08326, doi:10.1029/2012JA017858, 2012

Peter, R.: The ground-based millimeter-wave ozone spectrometerGROMOS, IAP Research Report, University of Bern, Switzerland, 13, 1997.

Peter, R. and Kämpfer, N.: Short-term variations of mid-latitude ozone profiles during the winter 1994/95, Proc. Third Europ. Symp. on Polar O 3 Res., 484-487, 1995.

Peter, R., Calisesi, Y., and Kämpfer, N.: Variability of middle atmospheric ozone abundances derived from continuous groundbased millimeter-wave measurements, Atmos. Ozone, 559-562, 1996.

Ricaud, P., de La Nó, J., Connor, B. J., Froidevaux, L., Waters, J. W., Harwood, R. S., MacKenzie, I. A., and Peckham, G. E.: Diurnal variability of mesospheric ozone as measured by the UARS microwave limb sounder instrument: Theoretical and groundbased validations, J. Geophys. Res. Atmos., 101, 10077-10089, doi:10.1029/95JD02841, 1996.

Rodgers, C. D.: Retrieval of atmospheric temperature and composition from remote measurements of thermal radiation, Rev. Geophys., 14, 609-624, doi:10.1029/RG014i004p00609, 1976. 
Roeckner, E., G. Bäuml, G., Bonaventura, L., Brokopf, R., Esch, M., Giorgetta, M., Hagemann, S., Kirchner, I., Kornblueh, L., Manzini, E., Rhodin, A., Schlese, U., Schulzweida, U., and Tompkins, A.: The atmospheric general circulation model ECHAM 5. PART I: Model description, MPI Tech. Report 349, Max Planck Institute for Meteorology, Hamburg, Germany, 2003.

Roeckner, E., Brokopf, R., Esch, M., Giorgetta, M., Hagemann, S., Kornblueh, L., Manzini, E., Schlese, U., and Schulzweida, U.: Sensitivity of Simulated Climate to Horizontal and Vertical Resolution in the ECHAM5 Atmosphere Model, J. Climate, 19, 4841-4872, doi:10.1175/JCLI3824.1, 2006.

Sakazaki, T., Fujiwara, M., Mitsuda, C., Imai, K., Manago, N., Naito, Y., Nakamura, T., Akiyoshi, H., Kinnison, D., Sano, T., Suzuki, M., and Shiotani, M.: Diurnal ozone variations in the stratosphere revealed in observations from the Superconducting Submillimeter-Wave Limb-Emission Sounder (SMILES) on board the International Space Station (ISS), J. Geophys. Res. Atmos., 118, 2991-3006, doi:10.1002/jgrd.50220, 2013.

Schanz, A., Hocke, K., and Kämpfer, N.: Daily ozone cycle in the stratosphere: global, regional and seasonal behaviour modelled with the Whole Atmosphere Community Climate Model, Atmos. Chem. Phys. Discuss., 14, 5561-5609, doi:10.5194/acpd14-5561-2014, 2014.

Schmidt, H., Brasseur, G. P., Charron, M., Manzini, E., Giorgetta, M. A., Diehl, T., Fomichev, V. I., Kinnison, D., Marsh, D., and Walters, S.: The HAMMONIA chemistry climate model: Sensitivity of the mesopause region to the 11-year solar cycle and $\mathrm{CO}_{2}$ Doubling, J. Climate, 19, 3903-3931, doi:10.1175/JCLI3829.1, 2006.

Schmidt, H., Brasseur, G. P., and Giorgetta, M. A.: Solar cycle signal in a general circulation and chemistry model with internally generated quasi-biennial oscillation, J. Geophys. Res. Atmos., 115, D00I14, doi:10.1029/2009JD012542, 2010.

Schneider, N., Selsis, F., Urban, J., Lezeaux, O., Noe, J., and Ricaud, P.: Seasonal and Diurnal Ozone Variations: Observations and Modeling, J. Atmos. Chem., 50, 25-47, doi:10.1007/s10874005-1172-z, 2005.

Steinbrecht, W., Claude, H., Schönenborn, F., McDermid, I., Leblanc, T., Godin, S., Song, T., Swart, D., Meijer, Y., Bodeker, G., Connor, B., Kämpfer, N., Hocke, K., Calisesi, Y., Schneider, N., Noe, J., Parrish, A., Boyd, I., Brühl, C., Steil, B., Giorgetta, M., Manzini, E., Thomasson, L., Zawodny, J., McCormick, M., Russel III, J., Bhartia, P., Stolarski, R., and Hollandsworth-Frith, S.: Long-Term Evolution of Upper Stratospheric Ozone at Selected Stations of the Network for the Detection of Stratospheric Change (NDSC), J. Geophys. Res., 111, D10308, doi:10.1029/2005JD006454, 2006.
Steinbrecht, W., Claude, H., Schönenborn, F., McDermid, I., LeBlanc, T., Godin-Beekmann, S., Keckhut, P., Hauchecorne, A., van Gijsel, J., Swart, D., Bodeker, G., Parrish, A., Boyd, I., Kämpfer, N., Hocke, K., Stolarski, R., Frith, S., Thomason, L., Remsberg, E., von Savigny, C., Rozanov, A., and Burrows, J.: Ozone and temperature trends in the upper stratosphere at five stations of the Network for the Detection of Atmospheric Composition Change, Int. J. Remote Sens., 30, 3875-3886, 2009.

Studer, S., Hocke, K., and Kämpfer, N.: Intraseasonal oscillations of stratospheric ozone above Switzerland, J. Atmos. Solar-Terr. Phys., 74, 189-198, doi:10.1016/j.jastp.2011.10.020, 2012.

Studer, S., Hocke, K., Pastel, M., Godin-Beekmann, S., and Kämpfer, N.: Intercomparison of stratospheric ozone profiles for the assessment of the upgraded GROMOS radiometer at Bern, Atmos. Meas. Tech. Discuss., 6, 6097-6146, doi:10.5194/amtd6-6097-2013, 2013.

Tilmes, S., Kinnison, D. E., Garcia, R. R., Müller, R., Sassi, F., Marsh, D. R., and Boville, B. A.: Evaluation of heterogeneous processes in the polar lower stratosphere in the Whole Atmosphere Community Climate Model, J. Geophys. Res. Atmos., 112, doi:10.1029/2006JD008334, 2007.

Tsou, J. J., Connor, B. J., Parrish, A., McDermid, I. S., and Chu, W. P.: Ground-based microwave monitoring of middle atmosphere ozone: Comparison to lidar and Stratospheric and Gas Experiment II satellite observations, J. Geophys. Res., 100, 30053016, doi:10.1029/94JD02947, 1995.

Vaughan, G.: Diurnal variation of mesospheric ozone, Nature, 296, 133-135, 1982.

Vaughan, G.: Mesospheric ozone theory and observation, Q. J. Roy. Meteorol. Soc., 110, 239-260, doi:10.1002/qj.49711046316, 1984.

Yuan, T., Schmidt, H., She, C. Y., Krueger, D. A., and Reising, S.: Seasonal variations of semidiurnal tidal perturbations in mesopause region temperature and zonal and meridional winds above Fort Collins, Colorado (40.6 $\left.{ }^{\circ} \mathrm{N}, 105.1^{\circ} \mathrm{W}\right)$, J. Geophys. Res., 113, D20103, doi:10.1029/2007JD009687, 2008.

Zommerfelds, W. C., Kunzi, K. F., Summers, M. E., Bevilacqua, R. M., Strobel, D. F., Allen, M., and Sawchuck, W. J.: Diurnal variations of mesospheric ozone obtained by ground-based microwave radiometry, J. Geophys. Res. Atmos., 94, 12819-12832, doi:10.1029/JD094iD10p12819, 1989. 